\title{
IS A RED CARD FOR LEARNERS' USE OF THEIR L1 IN L2 LESSONS FAIR? A SOCIOCULTURAL ACCOUNT
}

\author{
Le Van Canh*, Pham Thi Hang \\ Faculty of English, VNU University of Languages and International Studies,
} Pham Van Dong, Cau Giay, Hanoi, Vietnam

Received 29 April 2019

Revised 24 July 2019; Accepted 31 July 2019

\begin{abstract}
One of the controversial issues in second language acquisition research is the role of learners' first language in their second language learning. Traditionally, the first language was assumed to get in the way or interfere with the learning of the L2, and therefore, the first language must be banned in the foreign language classroom. However, this view has recently been reexamined and questioned by empirical studies conducted within the sociocultural perspectives. The goal of this paper is to provide new insights into the mediating role of the first language by reviewing those studies. The paper suggests that L1, when appropriately and systematically used, can be an enabling tool that scaffolds learners in completing cognitively complex and demanding L2 learning tasks. Towards this goal, research directions are also suggested. However, it is important to note that this paper is not intended to encourage teachers and learners to use the L1 in the L2 classroom unsystematically and inappropriately; rather, its goal is to encourage teachers to research their classroom in order to find optimal and effective use of L1 for mediating the success of L2 learning.
\end{abstract}

Keywords: crosslinguistic influence, L1 use, L2 learning, sociocultural theory, mediating, multicompetence

\section{Introduction}

The role of the first language (L1) in the learning of a second language (L2) has been widely studied as a source of crosslinguistic influence from the native system. Influenced by the Chomskyan essentialist ontology of language, which views that language resides in the mind and is separable from communication, many second language acquisition researchers during the $20^{\text {th }}$ century adopted a general-cognitive position towards language. Kellerman and Sharwood Smith (1986) suggested two different terms to refer to this influence: transfer and crosslinguistic

* $\quad$ Corresponding author. Tel.: 84-913563126

Email: levancanhvnu@gmail.com influence. Transfer, according to the authors, refers to processes that lead to the incorporation of elements of one language into another (e.g., borrowing or restructuring), while the term crosslinguistic influence, which is more inclusive, refers to transfer as well as any other kind of effect one language may have on the other (e.g., convergence or attrition). This perspective informed research on the role of L1 in L2 learning for several decades until the early 1990s. Since this assumption has been largely taken for granted in the language teaching literature throughout the twentieth century, with only isolated voices of dissent, a monolingual approach was strongly promoted in the language-teaching literature. Teachers and learners were advised 
not to use the learners' own language (L1) for explanation, translation, testing, classroom management or general interaction between teachers and students in the (L2) classroom for fear of the negative influence of L1 on L2 learning, leading to errors in L2. According to Prodromou (2002, p. 6), the issue of L1 use is a well-kept family secret for many, a "skeleton in the cupboard...a taboo subject, a source of embarrassment". Time and time again, L1 use in L2 classrooms was accompanied by feelings of guilt. West (1962, p. 48) argued that "One cannot but suspect that this theory of rigid avoidance of the mother tongue may be in part motivated by the fact that the teacher of English does perhaps not know the learner's mother tongue".

In a provocative article, Auerbach (1993, p. 13), who called the 'English-only' policy a 'neocolonialistic' policy, rang the bell warning of the ideology underlying the monolingual approach in second and foreign language education. By providing a sociopolitical account of the situation of immigrant ESL learners studying in the United States, she noted that classroom practices were not ideologically neutral, but influenced by the relations of power both inside and outside the classroom. She then rationalized the use of the L1 in ESL classrooms that

... starting with the $\mathrm{L} 1$ provides a sense of security and validates the learners' lived experiences, allowing them to express themselves. The learner is then willing to experiment and take risks with English (p. 19).

Auerbach's claim has opened a new research avenue which attempts to provide empirical evidence on the validity of the crosslinguistic influence on L2 learning. Insights from this research agenda have refuted the essentialist ontologies which hypothesized the compartmentalization of the two languages in the mind. Drawing on a psycholinguistic perspective, Cook's (1995; 2002;2008) coined the term 'multicompetence' meaning 'the knowledge of more than one language in the same mind' (2008, p. 231). According to this view, language learners are viewed as bilingual language users who are unlike monolinguals in the way they use their knowledge of both languages (L1 and L2). Thus, instead of discouraging or banning the use of L1 in the L2 classroom, learners should be encouraged 'to see the first language as something that is part of themselves whatever they do and appreciate that their first language is inextricably bound up with their knowledge and use of the second' (Cook, 2002, p. 339). According to Canargarajah (2015), 'multicompetence captures the idea that people multitask or parallel process with their languages, not keeping them disconnected when they are learning or using them' (p. 423).

By the turn of the century, scholars in critical sociolinguistics (Blommaert, 2010), critical educational linguistics (Makoni \& Pennycook, 2007), cognitive linguistics (Croft, 2001), usage-based linguistics traditions, which include emergentism, constructionism, complexity theory, dynamic systems theory, and conversation analysis, (Cadierno \& Eskildsen, 2015; Ellis, Römer, \& O’Donnell, 2016; Hopper, 1998; Kasper \& Wagner, 2014; LarsenFreeman, 2017; Verspoor, de Bot, \& Lowie, 2011), who espoused post-structuralist and interdisciplinary epistemologies, have moved away from the traditional essentialist view of language as a system that resides in the mind to a non-essentialist alternative view of language as a practice or a process. For example, Swain (2006) refers to this practice or process as 'languaging'. This ontological and epistemological shift has sparked a reconsideration of the role of learners' L1 in L2 learning. As Hall and Cook (2012, p. 299) put it, 
At the start of the twenty-first century, therefore, now that 'the long silence' (G. Cook, 2010: 20-37) about bilingual teaching has been broken, and its merits are no longer routinely ridiculed and dismissed, the way is open for a major 'paradigm shift' in language teaching and learning (Maley 2011). The literature reviewed in this article is no doubt only a beginning.

In a similar vein, Macaro (2014, p. 10) argues, "the question of whether the first language (L1) should be used in the oral interaction or the written materials of second or foreign language (L2) classrooms is probably the most fundamental question facing second language acquisition (SLA) researchers, language teachers and policy makers in this second decade of the $21^{\text {st }}$ century." In fact, the topic had figured prominently in numerous journals in the fields of applied linguistics, bilingualism, second language acquisition and second language education in the last few decades.

Despite the new discourses regarding the role of L1 in L2 learning, differences between native (L1) and nonnative (L2) linguistic behavior remain to be accounted for by the contested comparative fallacy (Bley-Vroman, 1983) in many Asian countries, including Vietnam. For example, Yin (2014) has pointed out that monolingual immersion ideologies are still dominant in many contexts in the world (especially in Southeast Asia) because of a whole host of ideologies, which have been strongly critiqued by recent research in multilingualism. Even at the current time, Lado's (1957) Contrastive Analysis with a focus on deterring L1 negative interference based on the assumption that individuals tended to transfer linguistic forms and meanings of their native language and culture to the foreign language and culture remains strongly influential to doctoral research within Vietnam.

The goal of this paper is, therefore, to cast doubt on this approach by providing the empirical evidence that has been documented in the literature in the last few decades. It is important to note that this paper is not intended to encourage teachers and learners to use the L1 in the L2 classroom unsystematically and inappropriately; rather its goal is to encourage teachers to research their classroom in order to find optimal and effective use of L1 for mediating the success of L2 learning. This secondary research is guided by the research questions:

1. Is learners' L1 inhibiting or enabling L2 learning?

2. What cognitive functions does L1 serve in L2 learning?

Because sociocultural theory (Lantolf, 2000) emphasizes the role of language as a cognitive mediator that the individual uses to gain control over the cognitive processes in performing cognitively demanding tasks, it is adopted to guide this research. What is discussed in this paper is a perspective on learners' use of their L1 to mediate their completion of complex L2 tasks. It does not mean teachers can use L1 unsystematically and habitually in teaching L2.

\section{Sociocultural perspectives on the role of L1 in L2 learning}

Over the last few decades, the field of second language education has witnessed the emergence of ever-growing empirical studies informed by the sociocultural theoretical framework viewing language not only as a means by which we communicate with others, but as a means by which we communicate with ourselves, as a psychological tool. 
Sociocultural theory is originated in Vygotsky's (1978) cognitive psychology, which was reinterpreted as Activity Theory by Leonti'ev (1978). When Jim Lantolf (2000) applied the theory to second language acquisition, he renamed the theory as sociocultural theory (SCT). Beginning with the doctoral dissertations by Negueruela (2003) on the use of Vygotsky's notion of conceptual knowledge as the primary unit of explicit instruction within the university Spanish course and Poehner (2005) regarding Dynamic Assessment as a strategy to diagnose and promote learner development, the body of SCT-informed research in second language instruction began to grow. Lantolf and Poehner (2014) use the concept of 'pedagogical imperative' to refer to the new orientation to SCT-informed research as a response to the call for research to be conducted in the teaching-research nexus in second language education (McKinley, 2019).

One of the central concepts in Vygotsky's theory is mediation, which is defined as "the creation and use of artificial auxiliary means of acting-physically, socially, and mentally" (Lantolf, p. 25). Mediation, "either by other or self [is] at the core of development and use" (Lantolf, 2011, p. 24). For Vygotsky (1978), language is the most important mediating tool of human cognitive development, i.e., regulating or organizing human thinking (Lantolf \& Thorne; 2006; Luria, 1982). Language serves as a symbolic artifact to facilitate social activities, in which and through which language is appropriated (Wertsch, 2007, p. 185).

Adopting this view of language, Swain (2006, 2010) uses the term 'languaging' to refer to this function of language. Unlike Lado (1979), who used "languaging" as a generic term to refer globally to various uses of language, Swain's (2006), "languaging" means the use of language to mediate cognitively complex acts of thinking. It is "the process of making meaning and shaping knowledge and experience through language" (Swain, 2006, p. 98). Swain and Lapkin (2013) elaborate this view, "What is crucial to understand here is that language is not merely a means of communicating what is in one person's head to another person. Rather, language serves to construct the very idea that one is hoping to convey. It is a means by which one comes to know what one does not know." (p. 105).

In this article, I adopt the sociocultural approach to the conceptualization of the cognitive functions that L1 serves in L2 learning because this approach is aligned with the multilingual turn in applied linguistics and second language learning research. The multilingual turn considers the L2 classroom as a bi/multilingual community of practice (Wenger, 1998) in which learners' L1 use is a legitimate practice which contributes to the classroom's 'conceptual architecture for learning' (p. 230). The approach is also aligned with the non-essentialist ontologies of language under the post-structural paradigm according to which language is viewed as a social practice rather than a system (Ortega, 2018). Finally, the sociocultural approach fits well with the findings generated from self-regulation research that self-regulated learners are flexible in using their cognitive and metacognitive strategies appropriately to accomplish their academic tasks (Wolters, 1998). When an individual L2 learner does languaging, s/he uses language to focus attention, to solve problems, to get himself or herself emotionally engaged, and so on. Inspired by these new insights into the role of L1 in L2 learning, a number of researchers (e.g. Antón \& DiCamilla, 1999; Thoms, Liao \& Szustak, 2005; Vilamil \& Guerrero, 1996) 
have reported interesting empirical evidence of how L1 is used as linguistic resources in L2 learning.

\section{Method}

Searches for peer-reviewed articles were conducted on Google Scholar by using key words. I used the terms relating to second language education such as second language acquisition, foreign language education, bilingualism combined with terms specific to the topic of this article such as the use of L1 in L2 learning, the role of L1 in L2 learning, and the influence of L1 on L2 learning. The initial searches provided 210,000 references, so I reduced the reference lists by gerenal relevance (according to title). I then read the abstracts to decide whether the articles were relevant to the purpose of my research or not. In the next step, I scanned the article to see if it matched my inclusion criteria, which required that studies (a) were empirical, (b) were published in international peer-reviewed journals, (c) used sociocultural perspectives as the theoretical framework for analysing and discussing the data. To satisfy these criteria, I examined methods, participants, setting, theoretical framework, and the orientation of the previous studies cited in each study. Since this article focused on the empirical evidence of the learners' use of L1 in L2 learning, articles on the teachers' and learners' attitudes towards, and/or beliefs about, the role of L1 in L2 learning were excluded. So were articles on teachers' use of L1 in the L2 classroom teaching and code-switching. A corpus of 19 articles, which were published in international peer-reviewed journals from 1993 to 2015 , met my criteria and was used in this study. After skimming the selected articles I classified them into three different themes: (i) role of L1 in collaborative tasks; (ii) role of $\mathrm{L} 1$ in reading comprehension; and (iii) role of L1 in writing tasks for an analysis. The term second language (L2) embraces both contexts, the foreign language context where learners have little exposure to the language they are learning outside of the classroom and the second language context or the 'L2-majority' context (Dixon et al., 2012). I also use the term L2 education to refer specifically to instructed language courses designed to develop learners' knowledge of, and competence in, an L2.

\section{Findings}

\subsection{L1 use in collaborative tasks in L2 classrooms}

According to my corpus, the study reported by Antón and Dicamilla (1999) was probably the first empirical study on the use of L1 in the collaborative interaction of adult learners. The study was conducted with a small group of native English-speaking students studying Spanish. Drawing on the sociocultural perspective on language as a psychological tool that mediates human mental activity on the external (interpsychological) and the internal (intrapsychological) planes, the researchers showed that learners used their L1 to define various elements of their task collaboratively, that is, to establish and maintain intersubjectivity. Also, L1 was shown to be an indispensable device for students in providing each other with scaffolded help. Finally, learners were reported to use their L1 to externalise their inner speech as a means of regulating their own mental activity throughout the process of task completion. Drawing on a similar sociocultural interactionist framework as Antón and Dicamilla (1999) did, Tomlinson 
(2000) stressed the importance of the inner voice in L2 learning. His findings indicated that when L2 learners made use of an L1 inner voice, they tended to fail in developing an L2 inner voice. While Tomlinson's study focused on understanding of the importance of helping L2 learners develop an L2 inner voice, he concluded his paper with the statement that the study helped to "find out how we can help learners of an L2 to make use of their L1 inner voice" (p.150). The findings of the study not only highlighted the critical functions of L1 in the second language learning process, but also showed how various communicative moves and linguistic forms were used to achieve these functions.

Furthering the inquiry into the functions of L1 use in L2 classrooms, Storch and Wigglesworth (2003) reported the results of their study which looked into the amount and the purpose of L1 use by twenty-four intermediate university English-as-a-secondlanguage (ESL) students in completing two tasks together: a text reconstruction task and a short joint composition task using a graphic prompt. These students shared similar variables such as age, educational background, and ESL proficiency level, and they were put in twelve pairs: 6 with a shared L1 and 6 with different L1s. Data was collected through audio-recorded pair talk and face-to-face interviews from six pairs with the common L1. Three pairs were Indonesian speakers and the other three pairs, Mandarin Chinese speakers. The authors reported that the learners used their L1 as a mediating tool for task management and task clarification in the joint composition task while they used their L1s mainly to clarify issues of meaning and vocabulary in the reconstruction task. However, the frequency of learners' use of their L1 varied greatly from minimal use among Chinese speakers to as much as $50 \%$ of the time in completing the tasks. These students also perceived that the use of their L1 was useful in meaning-focused activities. The researchers recommended that L1 use was "a normal psychological process that allows learners to initiate and sustain verbal interaction" (p. 768). Inspired by the results of these studies, Scott and de la Fluente (2008) explored the ways pairs of intermediate-level college learners of French and Spanish used the L1 and their second language (L2) to solve a grammar problem. Using conversation analysis of audiotaped interactions and stimulated recall sessions, they analysed the functions that L1 served while these students were engaged in consciousness-raising, formfocused grammar tasks. As revealed from the data, during a collaborative consciousnessraising, form-focused task, the students talked to themselves in the L1 as they translated the text, recalled grammar rules, reviewed the task, and planned what to say in the L2. The authors suggested that in case students were forbidden to use the L1, their two languages would compete, causing frustration and cognitive strain.

In a similar study, de la Colina and Mayo (2009) reported the findings of their study, which analysed the use of the L1 and its functions in the oral interaction of twelve pairs of undergraduate EFL learners with low proficiency in the target language while engaged in three collaborative tasks (jigsaw, text reconstruction and dictogloss). The findings indicated that the L1 was an important tool for these learners but the students' L1 use varied depending on the task types. In case of the dictogloss task, L1 was used more frequently to sequence and organize the information, which was provided orally in performing the dictogloss task than in doing the jigsaw and the text reconstruction task. In both tasks, learners made use of their L1 as a 
cognitive tool to access L2 forms, especially when they did not have enough resources in the L2 to complete tasks demanding a greater proficiency in the L2. These findings support DiCamilla and Antón's (2012) claim that "The fact that lower achieving learners presumably have a greater need for using L1 is not at all surprising if we consider the first language as a psychological tool used in moments of cognitive difficulty" (p. 166). De la Colina and Mayo suggested that the use of the L1 in the L2 classroom must not be considered offtask behavior.

The issue of task-related variation in L1 use was further supported by Storch and Aldosara (2010), who investigated the effect of learner proficiency pairing and task type on the amount of L1 (Arabic) used by learners of English as a foreign language (EFL) in pair work and the functions that the L1 served. Fifteen pairs of students, who were grouped according to their L2 proficiency as assessed by their own teachers. All pairs were assigned to complete three tasks - jigsaw, composition and text-editing - and their talk was audiorecorded, which was then transcribed for analysis to identify the amount of L1 (L1 words and L2 turns) these students used as well as the functions the L1 served. They reported that while the amount of L1 use in pair work activity was in general modest, it was more impacted by the task type than proficiency pairing. L1 was mainly used for the purpose of task management and to facilitate deliberations over vocabulary. When used for task management, L1 tended to reflect the kind of relationship the learners formed. When used for vocabulary deliberations, L1 was used not only to provide explanations to peers but also for private speech.

Swain and Lapkin (2013) investigated how two groups of Grade 8 French immersion learners in Canada used their L1 to complete two different collaborative tasks: dictogloss and jigsaw task. Each group was assigned to work on one of these tasks. The results showed that L1 served three main functions. These were moving the task along by establishing joint understanding of the task, focusing their attention on vocabulary and grammatical items (e.g., searching for vocabulary items or providing information and explanation about grammatical rules and conventions), and enhancing their interpersonal interaction. The most frequent function was moving the task along. Swain and Lapkin argued that L1 faciliated L2 classroom activities, particularly for low proficiency learners and on complex tasks such as the dictogloss task.

The findings of these studies were further supported by Bao and $\mathrm{Du}$ (2015), who explored how L1 (Danish) was used in L2 learning (Chinese) by beginner-level lower-secondary school learners of Chinese to complete taskbased activities in one secondary school in Denmark. The researchers reported that learners used their L1 with a high frequency while they were on-task in order to mediate their task completion. However, only a very small amount of L1 use was observed in offtask talk across tasks. Bao and Du suggested that L1 use was associated with a variety of factors such as learners' L2 proficiency, learning contexts and task types.

\subsection{The role of $L 1$ in $L 2$ reading comprehension}

'Mental translation' is the concept that draws the great attention of researchers who were interested in exploring the role of L1 in L2 reading comprehension. The concept means similarly with Vygotsky's (1986) concept of inner speech defined as an internalized language which is for oneself, as opposed to external, social speech produced for others. Probably, Kern (1994) was the pioneer research in this research avenue. $\mathrm{He}$ 
interviewed 51 students who spoke English as the first language and were studying French as the second language. He found L2 readers most frequently used mental translation in response to specific obstacles to comprehension, such as unfamiliar words and structures. Kern's (1994) study was replicated by Hawras (1996) who studied 27 students studying Spanish as a second language and the findings were similar to what reported in Kern's study. Hawras also found that advanced learners benefited more from mental translation in their L2 reading comprehension than less advanced learners. In another study, Upton (1997) used thinkaloud protocols to study native-speakers of Japanese studying English in an American university. He reported that less fluent L2 readers used their L1 more frequently for three cognitive functions: 1) wrestling with vocabulary they did not know or were not sure about; 2) seeking to gain a more global understanding of the L2 text; and 3) attempting to summarize or confirm what was understood. Upton and Lee-Thompson (2001) used think-aloud techniques and retrospective interviews with twenty native speakers of Chinese and Japanese at three levels of language proficiency studying in the U.S. to explore further the questions of when second language readers used their first language cognitive resources and how this cognitive use of the L1 helped them comprehend a second language text. As it was revealed in their study, L2 readers used their L1 to help them wrestle with word and sentence level problems, confirm comprehension, predict text structure and content, as well as monitor text characteristics and reading behavior.

\subsection{The use of L1 in completing writing tasks}

According to Kubota and Lehner (2004) while teaching English argument conventions, what learners bring from their L1 writing can also be used as a resource so that English conventions would become an additive rather than a subtractive force.

Kubota (1998) investigated whether individual Japanese university learners use the same discourse pattern in Japanese and English writing and how each individual's use of similar/dissimilar patterns affects the quality of ESL essays. These learners were asked to write one essay in English and another one in Japanese. Then, each of them was interviewed about their writing and views on rhetorical styles. The author reported that about half of the writers used similar patterns in L1 and L2 and that no negative transfer of culturally unique rhetorical patterns was found. In addition, the data suggested that Ll writing ability, English proficiency and composing experience in English affect the quality of ESL essays.

Wang and Wen (2002) used think-aloud protocols to investigate how a group of sixteen Chinese EFL learners used their L1 (Chinese) in composing two L2 writing tasks, narration and argumentation. They found that the learners were more likely to rely on L1 when they were managing their writing processes, generating and organizing ideas, but more likely to rely on L2 when undertaking task-examining and text-generating activities. Additionally, more L1 use was found in the narrative writing task than in the argumentative writing. Finally, the think-aloud protocols reflected that L1 use decreased with the writer's L2 development, but the extent of the decline of L1 use in individual activities varied.

van Weijen, van den Bergh, Rijlaarsdam, and Sanders (2009) also used think-aloud techniques to examine twenty-four Dutch learners' use of their first language (L1) while writing in their second language (L2). Twenty of these learners each wrote four short argumentative essays in their L1 (Dutch) 
and four in their L2 (English) under thinkaloud conditions. Findings revealed that all participants used their L1 while writing in their L2 to some extent, although this varied among conceptual activities. In addition, L2 proficiency was directly related to L2 text quality but was not related to the occurrence of conceptual activities either in L1 or L2. General writing proficiency, on the other hand, has a negative influence on L1 use during L2 writing and a positive effect on L2 use during L2 writing. L1 use during L2 writing is negatively related to L2 text quality, at least for Metacomments. Finally, L2 use appears to be positively related to L 2 text quality for Goal setting, Generating ideas, and Structuring, but negatively related to L2 text quality for Selfinstructions and Metacomments.

Yang (2014) conducted a longitudinal study that examined the meditational means that the three groups of ESL students at two Canadian business schools used in performing collaborative writing. Data was collected from multiple sources including interviews, class observations, group discussions, e-mails, field notes, and written materials. Results of data analysis showed that L1 and L2 served different functions. While L1 mediated the process of collaborative writing and "allowed the students to generate ideas and [...] facilitate their writing in L2" (p. 83), L2, on the other hand, provided students with opportunities for 'verbalization' or 'languaging', i.e., working together to solve linguistic problems and co-construct new knowledge of or about language.

An interesting study conducted by $\mathrm{Yu}$ and Lee (2014) focused on finding out the learners' use of L1 and L2 in peer feedback of L2 writing and the factors that influenced the students' code-switching in their peer written comments. Data was collected from 22 Chinese EFL learners' peer written comments on an essay and interviews with them. The authors found that these EFL learners used their L1 to give peer feedback on content and organization more than they did in L2. Also, learners' L1 use in giving peer written feedback resulted from the interaction of multiple factors such as their L2 proficiency, beliefs, learning goals, teacher requirements, teacher feedback practices, and power relationship between reviewers and writers. The researchers concluded that given the mediating role of $\mathrm{L} 1$, the use of $\mathrm{L} 1$ can allow students to attend to global areas of writing and enhance their peer feedback practices.

\section{Discussion}

According to Vygotsky (1997), cognitive and linguistic development is possible only when the meaning contained in the sign system is interpreted by the individual. Regarding the role of L1 in L2 learning, Vygotsky states, "in learning a new language one does not return to the immediate world of objects and does not repeat past linguistic developments, but uses instead the native language as a mediator between the world of objects and the new language" (Vygotsky, 1986, p. 161). He adds that learners make use of their L1 as a tool that mediates their understanding of task and content, and that supports their co-construction of L2. In the context of discussing alternative means of educating students who were blind, deaf, or mute, Vygotsky (1997) consistently emphasized the importance of retaining meaning and only changing the sign system. In clarifying Vygotsky's view on the relationship between sign and meaning, Díaz-Rico and Weed (2002, p. 2) note that "language and academic development is better approached through a respect for, and incorporation of, a student's primary language." In the context of second or foreign language learning, this 
view implies that learners' L1 is regarded as a cognitive tool which learners use to scaffold their L2 learning (Lantolf, 2000; Lantolf \& Poehner, 2014; Levine 2011; Swain \& Lapkin 2000).

All studies conducted within the sociocultural theoretical framework and reviewed in this paper show shared findings that the L1 may be a useful tool for learning the L2. Learners used their L1 for a number of cognitive functions, including enlisting and maintaining interest in the task as well as developing strategies and approaches to make a difficult task more manageable even in the form of private speech, i.e., speech for the self, speech that most often occurs covertly, but may surface when an individual needs to take control of his/her mental processes (Lantolf \& Thorne, 2006). Particularly, L1 facilitated them in completing collaborative learning tasks such as establishing a joint understanding of the task, and formulating the learners' goals (Brooks \& Donato (1994). In addition, L1 was used as a compensation strategy for task completion in case the learners' L2 proficiency was low (e.g. Swain \& Lapkin, 2013). These empirical findings lend support to Holliday's (1994) position that students working in groups or pairs do not have to speak English all the time; they can speak in their first language about a text and if through this process they are producing hypotheses about the language, then what they are doing is communicative.

Regarding L1 use in reading comprehension, the reviewed studies suggest that L1 mediates learners' sense-making of the structure, content, and meaning of the L2 reading text. In other words, learners use their L1 as a form of inner speech in an attempt to regain self-regulation in doing L2 learning tasks. In case of writing, L1 serves the functions of managing their writing processes, generating, organizing ideas, developing global writing skills, and even giving peer written feedback, particularly on content and discourse.

The empirical findings of all the reviewed studies suggest that L1, when used appropriately, systematically and purposefully, can have the enabling role rather than inhibiting L2 learning, and that "to restrict or prohibit the use of L1 in L2 classes is to deny learners the opportunity of using an important tool" (Storch \& Aldosari, 2010 , p. 372). In general, the use of L1 in L2 learning is found to be legitimatising L2 learners' multi-competent minds rather than artificially compartmentalising two languages during the process of L2 learning in the instructed context. As Swain and Lapkin (2013) recommend,

Learners should be permitted to use their L1 during collaborative dialogue or private speech in order to mediate their understanding and generation of complex ideas (languaging) as they prepare to produce an end product (oral or written) in the target language. However, as student proficiency in the L2 increases, learners should increasingly be encouraged to language using the $\mathrm{L} 2$ as a mediating tool. Further, when new and complex material is introduced within and across grades, learners should again be allowed to make use initially of their L1 to language, that is, to mediate their thinking (pp. 122-123).

The current epistemology no longer views L2 learning as an incremental and linear process and the L2 learner as "deficient communicator" (Firth \& Wagner, 1997, p. 
285). Instead, L2 learning is now viewed as a "dynamic process of ever-expanding meaning-making" (Byrnes, 2012, p. 21), in which learners as participants invest their bi/ multilingual repertoires and social identities (May, 2014, Ortega, 2018; Norton \& Toohey, 2011). This epistemology acknowledges the mediating role L1 plays when L2 learners have to cope with cognitively challenging L2 learning tasks when the tasks are too complex for them to process in their insufficiently developed L2. Hammerly (1991, p. 151) speculates that the judicious use of the learners' L1 in carefully crafted techniques "can be twice as efficient (i.e. reach the same level of second language proficiency in half the time), without any loss in effectiveness, as instruction that ignores the students' native language." Therefore, teachers, teacher educators, educational administrators, and language policymakers should free themselves of the fundamental misconceptions of the role of L1 as the source of failures in L2 learning and of the monolingual approach to second and/or foreign language learning and teaching in order to respect the happy marriage between L1 and L2 in the bi/multilingual era. It is unfair to the learners if a red card is used for their L1 use in L2 learning.

\section{Research directions}

The sociocultural perspective has boosted an interesting research agenda on how learners use their L1 in peer interaction. Insights gained from this research movement show that L1 can play a facilitating role in collaborative L2 learning tasks, be they forms-focused tasks or skills-focused tasks. However, it is important to note that valuing the role of L1 in L2 learning does not mean adopting a binary view of L1 versus L2. Rather, viewing L1 as a cognitive mediator as advocated by sociocultural theorists is to reconsider the use of L1 in relation to a wider classroom context and to acknowledge the cognitive functions that L1 serves in scaffolding the complex and cognitively challenging L2 learning tasks. Clearly, more research is needed. There are a number of practical issues that need to be empirically answered. For example, the role of the L1 when Vietnamese learners in different contexts are engaged in group work and pair work tasks, how they use their L2 expertise in completing different learning tasks in the classroom, and the ways that their L2 proficiency influences the amount and the way they use their L1 in cognitive processing. Findings from these investigations are bound to shed further light on the potentially role of the L1. As Vygotsky (1987) explained that one learns conceptually first by depending on one's L1 and masters the actual name of the word in an L2 only later, it is important to investigate the role of L1 in English-asmedium (EMI) or Content and Language Integrated Learning (CLIL) contexts. Li's (2017) concept of translanguaging is worth investigating. According to $\mathrm{Li}$, learning a new language does not necessarily mean unlearning an existing language. He goes on to state that

The actual purpose of learning new languages - to become bilingual and multilingual rather than to replace the learner's L1 to become another monolingual - often gets forgotten or neglected, and the bilingual, rather than monolingual, speaker is rarely used as the model for teaching and learning (p.8).

Regarding research methodology, because of the individuality, situatedness and taskrelated variation in the use of L1 among L2 learners, in-classroom research using qualitative methods such as think-aloud protocols, classroom observations, interviews, 
narratives, conversation analysis are likely to yield interesting and useful results. Exploratory Practice (Allwright, 2003; Hanks, 2017), which has recently been established as an innovative form of practitioner research in language education, can be an appropriate way forward. Exploratory Practice is "processoriented, integrated within everyday ways of working rather than something added to it and driven by the local concerns and needs of both teachers and learners" (Breen, 2006, p. 216). It offers opportunities for both teachers and learners to develop greater understandings of issues in the classroom (e.g. why do students use $\mathrm{L} 1$ in $\mathrm{X}$ task?) rather than finding a solution.

\section{Conclusions}

This secondary study is an endeavour to examine the role of L1 in L2 learning. To be more specific, it reviews the empirical studies that looked into the issue of languaging in second/foreign learning from a sociocultural theoretical lens. The goal of the study is to help Vietnamese EFL teachers, educational administrators, scholars and policymakers make better-informed decisions on the language use choices in the local foreign language classroom. One conclusion that is drawn from this study is that L1 can be a valuable resource that $\mathrm{L} 2$ learners use to cope with the complexity of L2 learning. A great amount of empirical evidence supports Vygotsky's (1987) view that L1 served as the knowledge foundation on which the learning of an L2 developed. According to this theory, the influence of L1 on L2 is twoway, which means that by simultaneously being exposed to two languages, one gains a deeper and broader understanding of both languages. By acknowledging learners' languaging, the traditional monolingual approach as well as the whole paradigm in second language education have to be shifted towards an epistemological diversity that views teachers as bilinguals, and learners as emerging bilinguals, rather than deficient language teachers and language learners. As the goal of English language education has been redefined as having students who are proficient L2 users not deficient native speakers, L1, when used appropriately, can be a beneficial linguistic resource (Butzkamm, 2003). That said, I do not mean that L1 can be used randomly and unsystematically. Teachers need to allow students use their L1 in a principled and purposeful way so that students are still exposed to comprehensible input, on the one hand, and, make use of their L1 resources when coping with cognitively and linguistically L2 learning tasks, on the other. Macaro (2009) advises teachers to find out about the reality of their context in order to find an optimal amount of L1. Excessive, unsystematic, random use of L1 is likely to deprive learners of the opportunity to use the target language, thereby demotivating learners in achieving their success in L2 learning.

\section{References}

Allwright, D. (2003). Exploratory Practice: Rethinking practitioner research in language teaching. Language Teaching Research, 7(2), 113-141.

Antón, M. \& F. DiCamilla (1999). Socio-cognitive functions of L1 collaborative interaction in the L2 classroom. The Modern Language Journal, 83(2), 233-247.

Auerbach, E. 1993. Reexaming English only in the ESL classroom. TESOL Quarterly, 27(1), 9-32.

Bao, R., \& Du, X. (2015). Learners' L1 use in a taskbased classroom: Learning Chinese as a foreign language from a sociocultural perspective. Journal of Language Teaching and Research, 6(1), 12-20.

Bley-Vroman, R. (1983). The comparative fallacy in interlanguage studies: The case of systematicity. Language Learning 33 (1), 1-17.

Blommaert, J. (2000). The sociolinguistics of globalization. Cambridge, UK: Cambridge University Press. 
Breen, M. P. (2006). Collegial development in ELT: the interface between global processes and local understandings. In S. Gieve and I. K. Miller (eds.). Understanding the Language Classroom (pp. 200225). Basingstoke: Palgrave Macmillan.

Brooks, F. B., \& Donato, R. (1994). Vygotskyan approaches to understanding foreign language learner discourse during communicative tasks. Hispania, 77, 262-274.

Butzkamm, W. (2003). We only learn language once. The role of the mother tongue in FL classrooms: Death of a dogma. Language Learning Journal, 28(1), 29-39

Byrnes, H. (2012). Of frameworks and goals of collegiate foreign language education: Critical reflections. Applied Linguistics Review, 3, 1-24.

Canagarajah, S. (2015). Clarifying the relationship between translingual practice and L2 writing: addressing learner identities. Applied Linguistics Review, 6(4), 415-440.

Cook, V. (1992). Evidence for multicompetence. Language Learning, 42(4), 557-591.

Cook, V. (1995). Multi-competence and learning of many languages. Language, Culture and Curriculum, 8.2, 93-98.

Cook, V. (2002). Language teaching methodology and the L2 user perspective. In V. Cook (Ed.), Portraits of the L2 user (pp. 325-344). Clevedon, UK: Multilingual Matters.

Cook, V. (2008). Second language learning and language teaching (4th edn). London: Hodder Education.

Croft, W. (2001). Radical construction grammar: Syntactic theory in typological perspective. Oxford, UK: Oxford University Press.

De La Colina, A. A., \& Gacia Mayo, M. D. P. (2009). Oral interaction in task-based EFL learning: The use of the L1 as a cognitive tool. International Review of Applied Linguistics (IRAL), 47, 325-345.

DiCamilla, F.J., \& Antón, M. (2012). Functions of L1 in the collaborative interaction of beginning and advanced second language learners. International Journal of Applied Linguistics, 22, 160-188.

Dixon, L. Q., Zhao, J., Shin, J.Y., Wu, S., Su, J. H., Burgess-Brigham, R., Unal Gezer, M. G., \& Snow, C. (2012). What we know about second language acquisition: A synthesis from four perspectives. Review of Educational Research, 82(1), 5-60.

Ellis, N.C., Römer, U., \& O’Donnell, M. B. (2016). Usage-based approaches to second language acquisition and processing: Cogitive and corpus investigations of construction grammar. Malden, MA: Wiley-Blackwell.

Firth, A., \& Wagner, J. (1997). On discourse, communication, and (some) fundamental concepts in SLA. The Journal of Modern Languages, 81(3), 285-300.
Hall, G. \& Cook, G. (2012). Own-language use in language teaching and learning: State of the art. Language Teaching, 45 (3), 271-308.

Hanks, J. (2017). Exploratory practice in language teaching: Puzzling about principles and practices. Switzerland: Springer.

Hammerly, H., 1991. Fluency and accuracy. Toward balance in language teaching and learning. Clevedon, UK: Multilingual Matters.

Hawras, S. (1996) Towards describing bilingual and multilingual behavior: Implications for ESL instruction. Unpublished MA thesis, University of Minnesota, Minneapolis.

Holliday, A.1994. Appropriate Methodology and Social Context. Cambridge, UK: Cambridge University Press

Hopper, P. J. (1998). Emergent grammar. In M. Tomasello (Ed.), The new psychology of language: Cognitive and functional approaches to language structure (pp. 155-175). Mahwah, NJ: Lawrence Erlbaum.

Kellerman, E. \& Sharwood Smith, M. (1986). Crosslinguistic influence on second language acquisition. Oxford: Pergamon Press.

Kern, R. G. (1994). The role of mental translation in second language reading. Studies in Second Language Acquisition, 16, 441-461.

Kubota, R. (1998). An investigation of L1-L2 transfer in writing among Japanese university learners: Implications for contrastive rhetoric. Journal of Second Language Writing, 7(1), 69-100.

Kubota, R. \& A. Lehner. (2005). "Response to Ulla Connor's comments." Journal of Second Language Writing, 14, 137-143.

Lado, R. (1957). Linguistics across cultures: Applied linguistics for teachers. Ann Arbor, MI: University of Michigan Press.

Lado, R. (1979). Thinking and "languaging": A psycholinguistic model of performance and learning. Sophia Linguistics, 12, 3-24.

Lantolf, J. P. (Ed.) (2000). Socio-cultural theory and second language learning. Oxford: Oxford University Press.

Lantolf, J. P. (2011). The sociocultural approach to second language acquisition: Sociocultural theory, second language acquisition, and artificial L2 development. In D. Atkinson (Ed.), Alternative approaches to second language acquisition (pp. 2447). New York, NY: Routledge.

Lantolf, J.P., \& Thorne, S.L. (2006). Sociocultural theory and the genesis of second language development. Oxford, UK: Oxford University Press.

Lantolf, J. P., \& Poehner, M. E. (2014). Sociocultural theory and the pedagogical imperative in L2 education: Vygotskian praxis and the research/ practice divide. New York, NY: Routledge. 
Larsen-Freeman, D. (2017). Complexity theory: The lessons continue. In L. Ortega \& Z-H. Han (Eds.), Complexity theory and language development: In celebration of Diane Larsen-Freeman (pp. 11-50). Amsterdam, Netherlands: John Benjamins.

Leonti'ev, A.N. (1978). Activity, consciousness, and personality. Translated from Russian by Marie J. Hall. Englewood Cliffs, NJ; London: Prentice-Hall.

Levine, G. (2011). Code choice in the language classroom. Bristol: Multilingual Matters.

Li, W. (2017). Translanguaging as a practical theory of language. Applied Linguistics, 39(1), 9-30.

Luria, A.R. (1982). Language and cognition. New York, NY: John Wiley and Sons.

Macaro, E .(2009). Teacher codeswitching in L2 classrooms: Exploring 'optimal use'. In T. Yoshida, H. Imai, Y. Nakata, A. Tajino, O. Takeuchi, \& V. Tamai (Eds), Researching language teaching and learning: An integration of practice and theory (pp. 293-304). Oxford: Peter Lang.

Macaro, E. (2014). Overview: Where should we be going with classroom codeswitching research? In R. Barnard \& J. McLellan (eds.), Codeswitching in university English-medium classes: Asian perspectives (pp. 10-23). Bristol, UK: Multilingual Matters.

Makoni, S., \& Pennycook, A. (Eds.). (2007). Disinventing and reconstituting languages. Clevedon, UK: Multilingual Matters.

McKinley, J. (2019). Evolving the TESOL teachingresearch nexus. TESOL Quarterly (Early view Online version)

May, S. (2014). The multilingual turn: Implications for SLA, TESOL, and bilingual education. New York, NY: Routledge.

Negueruela, E. (2003). A sociocultural approach to the teaching and learning of second languages: Systemic-theoretical instruction and L2 development. Unpublished doctoral dissertation, The Pennsylvania State University, University Park, PA.

Norton, B., \& Toohey, K. (2011). Identity, language learning, and social change. Language Teaching, 44(4), 412-446.

Ortega, L. (2018). SLA in uncertain times: Disciplinary constraints, transdisciplinary hopes. Working Papers in Educational Linguistics (WPEL), 33(1), 1-30.

Poehner, M. E. (2007). Dynamic assessment of advanced L2 learners of French. Unpublished doctoral dissertation, The Pennsylvania State University, University Park, PA.

Prodromou, L. (2002). The role of the mother tongue in the classroom. International Association of Teachers of English as a Foreign Language Issues, 6-8.

Sešek, U. (2007). English for teachers of EFL-Toward a holistic description. English for Specific Purposes, 26, 411-425.
Scott, V. M., \& de la Fluente, M. J. (2008). What's the Problem? L2 Learners' Use of the L1 During Consciousness-Raising, Form-Focused Tasks. The Modern Language Journal, 92(1), 100-113).

Storch, N., \& and Wigglesworth, G. (2003). Is There a Role for the Use of the L1 in an L2 Setting? TESOL Quarterly, 37(4), 760-770.

Storch, N., \& Aldosara, A. (2010). Learners' use of first language (Arabic) in pair work in an EFL class. Language Teaching Research, 14(4), 355-375.

Swain, M. (2006). Languaging, agency and collaboration in advanced second language learning. In $\mathrm{H}$. Byrnes (Ed.), Advanced language learning: The contribution of Halliday and Vygotsky. London: Continuum.

Swain, M. (2010). Talking it through: Languaging as a source of second language learning. In R. Batstone (Ed.), Sociocognitive perspectives on second language learning and use (pp. 112-129). Oxford, UK: Oxford University Press.

Swain, M., \& Lapkin, S. (2013). A Vygotskian sociocultural perspective on immersion education: The L1/L2 debate. Journal of Immersion and Content-Based Language Education, 1(1), 101-129.

Tomlinson, B. (2000). Talking to yourself: The role of the inner voice in language learning. Applied Language Learning, 11(1), 123-154.

Upton, T. A. (1997). First and second language use in reading comprehension strategies of Japanese ESL students. TESL-EJ, 3(1), 1-27.

Upton, T. A., \& Lee-Thompson, L. (2001). The role of the first language in second language reading. Studies in Second Language Acquisition, 23(4), 469-495.

van Weijen, D., van den Bergh, H. Rijlaarsdam, G. Ted Sanders, T. (2009). L1 use during L2 writing: An empirical study of a complex phenomenon. Journal of Second Language Writing, 18, 235-250.

Verspoor, M., de Bot, K., \& Lowie, W. (Eds.). (2011). A dynamic approach to second language development: Methods and techniques. Amsterdam, Netherlands: John Benjamins.

Vilamil, O. S. \& M. de Guerrero (1996). Peer revision in the L2 classroom: Social-cognitive activities, mediating strategies, and aspects of social behaviour. Journal of Second Language Writing, 5(1), 51-75.

Vygotsky, L.S. (1978). Mind in society: The development of higher psychological processes (M. Cole, V. John-Steiner, S. Scribner \& E. Souberman, Trans.). Cambridge, MA: Harvard University Press.

Vygotsky, L.S. (1978). Mind in society: The development of higher psychological processes (M. Cole, V. John-Steiner, S. Scribner \& E. Souberman, Trans.). Cambridge, MA: Harvard University Press.

Vygotsky, L. S. (1986). Thought and language (A. Kozulin, trans.). Cambridge, MA: The MIT Press. (Original work published in 1934). 
Vygotsky, L.S. (1987). Thinking and speech. In R. Rieber \& A. Carton (Eds.), The collected works of L.S. Vygotsky (N. Minick, Trans.) (vol. 1, pp. 39285). New York: Plenum Press

Vygotsky, L.S. (1997). Educational psychology. Boca Raton, FL: St. Lucie Press.

Wang, W., \& Wen, Q. (2002). L1 use in the L2 composing process: An exploratory study of 16 Chinese EFL writers. Journal of Second Language Writing, 11(3), 225-246.

Wenger, E. (1998). Communities of practice: Learning, meaning and identity.Cambridge, UK: Cambridge University Press.

Wertsch, J. V. (2007). Mediation. In H. Daniels, M. Cole, \& J. V. Wertsch (Eds.), The Cambridge companion to Vygotsky (pp. 178-192). New York: Cambridge University Press.

West, M. (1962). Teaching English in difficult circumstances. Teaching English as a foreign language with notes on the techniques of textbook construction. London, UK: Longmans, Green and Co.

Wischgoll A. 2016. Combined training of one cognitive and one metacognitive strategy improves academic writing skills. Frontiers in Phycology, 7,1-14.

Wolter, C. A. (1998). Self-regulated learning and college student's regulation of motivation. Journal of Educational Psychology, 90(2), 224-235.

Yang, L. (2014). Examining the mediational means in collaborative writing: case studies of undergraduate ESL students in business courses. Journal of Second Language Writing, 23, 74-89.

Yin, A. M. Y. (2014). Conceptualising the potential role of L1 in CLIL. Language, Culture and Curriculum, 28(1), 74-89.

Yu, S., \& Lee, I. (2014). An analysis of Chinese EFL students' use of first and second language in peer feedback of L2 writing. System, 47, 28-38.

\title{
CẤM SỬ DỤNG TIẾNG MẸ ĐẺ TRONG GIÒ' HỌC NGOẠI NGƯ' CÓ CÔNG BẰNG KHÔNG? CÂU TRẢ LỜ'I TỪ LÝ THUYẾT VĂN HÓA-XÃ HộI
}

\author{
Lê Văn Canh, Phạm Thị Hằng \\ Khoa Tiếng Anh, Trường Đại học Ngoại ngũ - ĐHQGHN, \\ Phạm Văn Đồng, Cầu Giấy, Hà Nội, Việt Nam
}

Tóm tắt: Vai trò của tiếng mẹ đẻ trong quá trình học ngoại ngữ là một trong những vấn đề gây tranh cãi trong nghiên cứu về quá trình thụ đắc ngôn ngữ thứ hai. Trong một thời gian dài, tiếng mẹ đẻ được cho là yếu tố gây cản trở hoặc ảnh hưởng tiêu cực tới quá trình học ngoại ngữ, do vậy giáo viên và học sinh không được phép sử dụng tiếng mẹ đẻ trong các giờ học ngoại ngữ. Tuy nhiên, các kết quả nghiên cứu theo lý thuyết văn hóa-xã hội gần đây đã phản bác lại quan niệm này và các nhà nghiên cứu đã đặt lại vấn đề về vai trò của tiếng mẹ đẻ theo những quan điểm lý thuyết mới. Bài viết này có mục đích cung cấp những chứng cứ khoa học và những quan điểm về vai trò hỗ trợ quá trình học ngoại ngữ của tiếng mẹ đẻ đã được công bố trên các tạp chí khoa học quốc tế có uy tín. Từ kết quả phân tích những kết quả khoa học đó, bài viết đưa ra nhận xét rằng nếu được sử dụng hợp lý thì tiếng mẹ đẻ sẽ có vai trò hỗ trợ người học phát triển năng lực ngoại ngữ thông qua việc hoàn thành những hoạt động ngôn ngữ khó. Để phát huy được lợi ích của tiếng mẹ đẻ trong quá trình học ngoại ngữ, bài viết cũng đưa ra những gợi ý về các hướng nghiên cứu cũng như phương pháp thực hiện các hướng nghiên cứu đó.Tuy nhiên, cần nhấn mạnh rằng bài viết này không có mục đích khuyến khích giáo viên và học sinh sử dụng tiếng mẹ đẻ một cách tùy tiện trong học ngoại ngữ mà mục đích là khuyến khích giáo viên tìm cách sử dụng tiếng mẹ đẻ một cách hợp lý và có nguyên tắc để giúp người học học ngoại ngữ tốt hơn.

Tù khóa: ảnh hưởng giao ngữ, sử dụng ngôn ngữ thứ nhất, học ngôn ngữ thứ hai, lý thuyết văn hóa xã hội, trợ giúp trung gian, ngữ năng tổng hợp 